\title{
AN ANALYSIS OF FIGURATIVE LANGUAGE USED IN EDGAR ALLAN POE'S POEMS
}

\author{
Dewi Syafitri ${ }^{1}$ \\ STKIP PGRI Lubuklinggau \\ Melisa Marlinton ${ }^{2}$ \\ STKIP PGRI Lubuklinggau \\ dewi2018@gmail.com ${ }^{1}$
}

Submit, 29-11-2018 Accepted,21-12-2018 Publish,21-12-2018

\begin{abstract}
The objectives of the research was to describe kinds and meanings of figurative language used in Edgar Allan Poe's poems. The titles of the 8 Edgar Allan Poe's poems were "Annabel Lee, The Sleeper, A Dream Within A Dream, To One in Paradise, Alone, Spirit of the Death, The Lake and Evening Stars". Descriptive qualitative method was used to classify and analyze the data. The technique used in collecting the data was library research. Meanwhile, in analyzing the data, the researchers applied qualitative descriptive. After investigating the kinds and meanings in 8 Edgar Allan Poe's poems, the researchers found 96 figurative languages. The figurative language in Edgar Allan Poe's poems have been analyzed in kinds; there were 25 personifications, 6 similes, 16 metaphors, 11 hyperboles, 2 ironies, 9 paradoxes, 6 metonymies, and 21 symbols. The meanings of figurative languages found in Edgar Allan Poe's poem were classified into 42 connotative meanings, 30 social meanings, 16 reflected and 8 collocative meanings. The conclusion of this research was Edgar Allan Poe's poems are important to be read because the poems were rich with the using of figurative language which can attract the readers' attention and evoke readers' imagination.
\end{abstract}

Keyword: semantics, figurative language, poems.

\section{INTRODUCTION}

Language plays a great part in human life. Distinguishing man from animal absolutely can be seen from language (Bloomfield, 1933:3). A poet of language used knowledge and abilities in language to deliver communication with each other, ideas, hypotheses, emotions, desires, and all the other things that need to be expressed. Furthermore, these knowledge systems are studied in scientific way; it is called linguistics. 
Linguistics is the scientific study of language - how it is put together and how it functions. According to Abrams (1999:140) "Linguistics is the systematic study of the elements of language and the principles governing their combination and organization". Linguistics can be divided into three categories or subfields of study: 1) language in context, 2) language meaning, and 3) language form. In linguistics, the study of meaning is devoted to semantics.

Semantics is a study of the meaning as a branch of linguistics. Linguistic itself has brought to the subject of semantics a certain degree of analytic rigour combined with a view of the study of meaning as an integrated component within the total theory of how language works (Leech, 1981:10).

Leech (1969:5), explaining and describing the meaning in natural language is the aim of semantics. People may even say in ordinary usage more explicit that the goal of semantics is to explain what underlies the use of the word means and related term (sense, nonsense, signify, ambiguous, antonym, synonymy, etc.) in English and other language. The language which uses the unreal meaning is called figurative language in semantic analysis. Figurative language can be understood through studying semantics.

Perrine and Thomas (1983:81) stated that figurative language is a persuasive language. It is another way of adding an extra dimension to language, which can attract the reader's attention. Figurative languages conveys meaning or heighten effect, it will give more meaning to the words, beautify them, and emphasize their meaning. Because of some reasons above, figurative language is one important elements of poem. Figure of speech is one of the important intrinsic elements in a poem which is more dominant than other element". The use of figurative language make the poems sound more beautiful, and the uses of such figures also make poems attract the reader's attention.

Knickerbockers and Williard (1963:310) state that poem is the fusion of sound and sense or a melting together of sound and sense. Poem might be defined as a kind of language that says it more intensely than does ordinary language. A special way of using words is by using figurative of language that is usually used by the poet to attract the reader attention, colored the poem and make the poem interesting to read. There are a lot of things that can be discussed in a poem, but this research analysis concentrates only on the analysis of the figurative language used in the poem. Edgar Allan Poe's poems are chosen to analyze because they are rich with the kinds of figurative language.

According to Ingram (1899:8) "Edgar Allan Poe was one of the genius American poet is capable for communicate his sense to poems". He has used a lot of figurative languages in his poems.

According to Padni (2012:2) the idea and message of a poem sometimes difficult to understood by the people. In other to find out at least the idea of the 
poem, people should have basic knowledge about figurative language, since the ideas in a poem are mostly conveyed in figurative language.

This research focused on analyzing the kinds and meanings of figurative language that occur in Edgar Allan Poe's poems. It was considered as an important thing to understand what actually the meanings which contain within the poems. Because it is useless, if people just read the poems without understanding what actually the poets want to convey to the readers. Thus, people need to analyze figurative language in poems more deeply.

Some previous studies by Iriyanti (2010:5), Agustini (2016:6) and Suryani (2013:3) that discussed about the use of figurative language in Poems in literature side and they just analyzed one or three poems. Meanwhile, the researchers are interested to discuss by linguistics side and expand this research through analyzing kinds of figurative language and explain in detail about the meanings of figurative language found in five of Edgar Allan Poe's poems. This research will help the readers expand the literary appreciation, increase the knowledge and understand or have high interpretation of the meaning in poem especially Edgar Allan Poe which contains some figurative sentences.

\section{LITERATURE REVIEW}

Semantics is a branch of linguistics which relates with meaning. A study of meaning in language is considered as semantics. Words, phrases and sentences include as the expression of linguistic objects. Syntactical arrangement or pronunciation of linguistics object does not matter or does not need serious attention.

Semantics has developed and became valuable study. There are two factors that make semantics become important and worthy study. First, meaning is strictly related to communication. A certain meaning can be conveyed in communication that plays important role in our life. Second, the use of reasoning and perception in mental ability is as the process of human attempts to comprehend the nature of meaning.

Semantics is not only the center of communication study but also the center of the study of the human mind thought processes, cognition, conceptualization-all these are intricately bound up with the way in which we classify and covey our experience of the world through language. Leech (1981:9) states that semantic has often seemed baffling because there are many different approaches to it, and the ways in which they are related to one another rarely clear, even to writes on subject. It has also seemed bluffing because it is 'cogniting turning in upon itself'.

In semantic analysis, the language which uses the unreal meaning is called figurative language. One way to understand a figurative language is by studying 
semantics. Abrams (1999:96) defined figurative languages a conspicuous departure from what users of a language apprehend as the standard meaning of words, or else the standard order of words, in order to achieve some special meaning or effect. Figures are sometimes described as primarily poetic, but they are integral to the functioning of language and indispensable to all modes of discourse.

When the sentence has hidden the meaning, non-literally meaning or figurative meaning exists beside it. Non-literal meaning would be more difficult to understand without knowing the context, the situation or atmosphere of sentence being expresses. As stated by Crystal (1999:116) "Figure of Speech is an expressive use of language where words are used in a non-literal way to suggest illuminating comparisons and resemblances."

Figurative language is often found in literary works, such as; articles in newspaper or magazine, ads, novels, poems, etc. Figurative language is the use of words that go beyond their ordinary meaning. It requires using the imagination to figure out the poet's meaning. When a researcher uses literal language, he or she is simply stating the facts as they are. Figurative language, in comparison, uses exaggerations or alterations words to make a particular linguistic point.

There are many kinds of figurative language. Leech (1981:11) has classified figurative meaning into 8 types. They are: personification, simile, metaphor, hyperbole, irony, litotes, metonymy and oxymoron. Meanwhile, Abrams (1999: 90) divides it becomes ten kinds; they are metaphor, simile, synecdoche, personification, metonymy, allegory, overstatement (hyperbole), irony, symbolism, and paradox. These are the types of figurative languages commonly used by poets all over the world:

\section{Kinds of Figurative Language Personification}

Personification is a kind of figurative expressions in which an animate object given a human quality. The word personification derives from Latin words; 'persona' means person, actor, or mask used I the theatre and 'fix' means to make. According to Abrams (1999:99) "Personification, in which either an inanimate object or an abstract concept is spoken of as though it were endowed with life or with human attributes or feelings".

\section{Simile}

Simile is a kind of figurative meaning comparing two essentially unlike things. Simile expresses a direct comparison between things, which have one or more points in common and be recognized by the use of the word 'like' and 'as'. 
As stated by Abrams (1999:97), "in a simile, a comparison between two distinctly different things is explicitly indicated by the word 'like' or 'as"'.

\section{Metaphor}

The word metaphor comes from Greek; it means to carry over. In a metaphor, a word or expression that in literal usage denotes one kind of thing is applied to a distinctly different kind of thing, without asserting a comparison (Abrams, 1999:97). This statement is supported by Perrine (1963:571), metaphor is the process of comparing two unlike things as if they are one. This thing happened because metaphor does not have connective words such as like, as, than, similar to and seems determining them as figurative.

\section{Hyperbole}

According to Abrams (1999:120) "Hyperbole is bold overstatement, or the extravagant exaggeration of fact or of possibility. It may be used either for serious or ironic or comic effect". Hyperbole, like the other two figures, is frequently concerned with personal values and sentiment; that is, with making subjective claims which, however exaggerate (Leech, 1969:168).

\section{Irony}

According to Abrams (1999:135), In most of the modern critical uses of the term 'irony' there remains the root sense of dissembling or hiding what is actually the case; not, however, in order to deceive, but to achieve special rhetorical or artistic effects. Irony is a way of speaking or writing by saying something while the meaning is another. It refers to a situation in which reality differs from appearance. It occurs in sentence or words when they imply contrast or opposite meaning.

\section{Paradox}

The term Paradox is from the Greek word "paradoxon" that means contrary to expectations, existing belief or perceived opinion. It is a statement that appears to be self-contradictory or silly but may include a latent truth. A paradox is often used to make a reader think over an idea in innovative way. As stated by Abrams (1999:201), A paradox is a statement which seems on its face to be logically contradictory or absurd, yet turns out to be interpretable in a way that makes good sense.

\section{Metonymy}

Metonymy is a change of name, the use of the one word for another, the use of an idea by means of terms involving association. As stated by Abrams 
(1999: 98), "metonymy (Greek for "a change of name") is the literal term for one thing is applied to another with which it has become closely associated because of a recurrent relationship in common experience".

\section{Symbolism}

Symbolism is applied only to a word or phrase that signifies an object or event which in its turn signifies something, or has a range of reference, beyond itself (Abrams, 1999:311). Symbolism is a thing (could be an object, person, situation or action) which stands for something else more abstract. Many poets have used the rose as a symbolism of youth and beauty; a flag is a symbolism of a nation (Fadaee, 2011:2).

Meaning plays a very important role in communication. There would be no language without meaning. Language is an instrument for delivering the meaning. Leech (1969:5) says "The aim of semantics is to explain and describe meaning in natural language". By paying attention to the definitions above, the word "meaning" has a number different notions and varieties since poet use a word to mean something different from what it denotes in expressing their ideas, minds, feeling.

\section{Seven Types of Meaning}

Leech (1981:8-23) has defined seven types of meaning. The seven types of meaning are as follows:

1. Conceptual meaning is a word based on the structure and form of the word that has clear and logical definition.

2. Connotative meaning is words or sentences that have implied or explicit meaning. For example, the word "red" has the connotation of brave and the word "black" has the connotation of magic, evil or fear.

3. Social meaning is a piece of language conveys about the social circumstances of it use. It is connected with the situation in which an utterance is uttered. For examples, the words 'horse, steed and hag' have the same conceptual meaning but the convey different social circumstances of their use.

4. Affective meaning is meaning that expresses the personal feelings or attitude of the speakers or the writers. For example, "I'm very glad to hear your voice, but I wonder if you would be so kind as to lower your voices a little".

5. Reflected meaning is the meaning that arises in case of multiple conceptual meaning when one sense of a word forms part of our response to another sense. For example, it has become increasingly difficult to use term like intercourse, ejaculation, and erection, in 'innocent' senses without conjuring up their sexual associations.

6. Collocative meaning consists of the association of a word acquires on account of the meanings of words which tend to occur in its environment. For 
example, The word 'handsome' and 'beautiful' have common ground in the meaning 'good looking'. The word 'handsome' refers to man and 'beautiful' refers to woman.

7. Thematic meaning means what is communicated by the way in which a speaker or writer organizes the message in terms of ordering, focus and emphasis. It is usually applied in the use of active and passive forms.

There are two kinds of meaning, they are literal meaning and non-literal meaning. Saputri $(2014: 14)$ states that literal meaning is when the poet says something that has natural meaning or does not have other meaning. While, nonliteral meaning is a kind of meaning which means something different from what the word means. Non-literal meaning occurs when the speaker means different from the word or sentences really means.

Poem is a universal as language and almost as ancient. The most primitive people have used it, and the most civilized have cultivated it because it has given pleasure. People have read it, listen to it, or recited it because they liked it and give them enjoyment.'

According to Childs \& Fowler (2006:181), The terms 'poem', 'poetry', 'poetic' and 'poetics' seem to be necessarily frequent in critical writing but various in their senses. Poem use certain language it is ordinary language that people use everyday. It takes an origin from emotion recollected in tranquility. To beautify the poem usually people use certain language. This is necessary because when the poems researcher in ordinary language, it make no strong impression to the readers.

\section{Elements of Poem}

The basic element of poem is a set of instruments used to create a poem become more powerful and enticing. These are elements of poems commonly used by poets in the world:

\section{Imagery}

According to Perrine (1963:45) "imagery may be defined as the representation through language of sense experience". Imagery is one of the most common in criticism, and one of the most variable in meaning.

\section{Rhythm}

The term rhythm refers to any wavelike recurrence of motion and sound. In speech it is the natural sense and fall of language. 


\section{Rhyme}

A rhyme is placed in the end of lines in poem or song which is a repetition of similar sounding words. According to Abrams (1999:273) "In English versification, standard rhyme consists of the repetition. Rhyme is identity in sound of some part, especially the end, of words or lines of verse".

\section{Tone}

Tone, in literature, may be defined as the researcher's or poet's attitude toward his subject, his audience or himself. It is the emotional coloring, or the emotional meaning, of the work and is an extremely important part of the full meaning (Abrams, 1999:177).

\section{Figurative Language}

Abrams (1999:97), "Figurative languages are sometimes described as primarily poetic". Figurative Language is a conspicuous departure from what users of a language apprehend as the standard meaning of words, or else the standard order of words.

\section{Forms of Poems}

All kinds of poems are written in several styles. These styles are defined by the number of lines in each stanza. These are forms of poems commonly used by poets all over the world:

\section{Blank verse}

Abrams (1999:24) stated that blank verse consists of lines of iambic pentameter (five-stress iambic verse) which are unrhymed-hence the term "blank".

\section{Sonnet}

According to Abrams (1999:290) "Sonnet is A lyric poem consisting of a single stanza of fourteen iambic pentameter lines linked by an intricate rhyme scheme". The English or Shakespearean sonnet is made up of three quatrains and a couplet and rhymes abbacddceffegg".

\section{Heroic Couplet}

Abrams (1999:114) stated that heroic couplet is a pair of ten-syllable lines that rhyme: a poem as a whole can be written in a sequence of heroic couplets. A heroic couplet commonly used in epic and narrative poetry, and consists of a rhyming pair of lines in iambic pentameter. 


\section{Ballad}

Ballad is a song, transmitted orally, which tells a story. According to Abrams (1999:18) "Ballads are thus the narrative species of folk songs, which originate, and are communicated orally, among illiterate or only partly literate people".

\section{Limerick}

A limerick is a form of poetry in five-line, with a strict rhyme scheme (aabba), which is sometimes obscene with humorous intent (Peck and Coyle, 1984:41). Limericks are humorous, rhyming; five lines poems with a specific rhtyhm pattern and rhyme scheme.

\section{Free Verse}

Free Verse is sometimes referred to as "open form" verse, or by the French term vers libre. Most free verse also has irregular line lengths, and either lacks rhyme or else uses it only sporadically (Abrams, 1999:105).

\section{Haiku}

Haiku is a Japanese poetic form that represents, in seventeen syllables, ordered into three lines of five, seven, and five syllables (Abrams, 1999:114).

\section{RESEARCH METHOD}

The researchers analyzed and described the kinds and meanings in the 8 Edgar Allan Poe's poems, entitled Annabel Lee, The Sleeper, A Dream Within A Dream, Alone, To One in Paradise, Spirit of the Dead, The Lake and Evening Star.

Research design is plan and the procedure for research that focus the decision from broad assumption to detailed methods of data collection and analysis. This research was qualitative research. To be more specific, the type of this research was mostly descriptive qualitative research. Descriptive analysis means to describe what actually happen to procedures about method which are useful in research.

Descriptive qualitative approach contains sentences or description of the objects and does not display the detail arithmetic calculation and statistic (Moleong, 2009:11). This research used the descriptive qualitative research because this research used non numeral data that had purpose to describe and analyze the types and meaning of figurative language used in Edgar Allan Poe's poems. This research was carried out by formulating problem, collecting data, classifying data, and analyzing data. 
In this research, the primary or main data came from Edgar Allan Poe's poem. The poems were analyzed based on their kinds and meanings of figurative language used in Edgar Allan Poe's poems. If the primary data came from the Edgar Allan Poe's poem, the secondary data came from articles, books, journal and other literatures.

Technique for collecting the data was a technique to get and collect the data. In order to get some data were required in this research, the researchers conducted library research. Library research is the study that use library source to get information. In this research, the researchers used analysis of documents for collecting the data.

The technique of the data analysis used in this research is qualitative research because the object of the research was in the form of words not in numbers. In doing the analysis the researchers went through the procedures as follows: (1) identifying the kinds of figurative language contain in Edgar Allan Poe's poems, (2) reducing the unnecessary data, (3) classifying the kinds of figurative languages, (4) analyzing the figurative language based on kinds and also the meanings of figurative languages; and, (5) drawing conclusion of the data that had been analyzed.

\section{FINDING}

There were some findings in this research including the kinds of figurative language based on the word classification (word, phrase, and sentence) and the meanings of figurative language. In this research, the researchers analyzed 8 Edgar Allan Poe's poems entitled Annabel Lee, The Sleeper, A Dream Within A Dream, Alone, To One in Paradise, Spirit of the Dead, The Lake and Evening Star.

\section{Kinds of Figurative Language}

There are many kinds of figurative language. This research focused on 8 kinds of figurative language including personification, metaphor, simile, hyperbole, irony, paradox, metonymy, and symbolism.

In this section, the researchers just described 8 poems of Edgar Allan Poe's poem entitled Annabel Lee, The Sleeper, A Dream Within A Dream, Alone, To One in Paradise, Spirit of the Dead, The Lake and Evening Star. These are the kinds of figurative languages used in Edgar Allan Poe's poems:

\section{Annabele Lee}

The poem "Annabel Lee" consisted 41 lines. There were 13 lines that used figurative language in the Annabele Lee. From the table above, the researchers found 10 figurative language in this poem. 


\section{The Sleeper}

This poem consisted 60 lines. There were 23 lines that used figurative language in the Annabele Lee. From the table above, the researchers found 17 figurative languages in this poem.

\section{A Dream Within A Dream}

This poem first published in 1849. There were 15 lines that used figurative language in the A Dream Within A Dream. From the table above, the researchers found 11 figurative languages in this poem.

\section{Alone}

"Alone" consists 22 lines. There were 11 lines that used figurative language in Alone. There were 10 figurative languages found in the poem.

\section{To One in Paradise}

This poem first published in 1832. There were 13 lines that used figurative language in To One in Paradise from the table above the researchers found 11 figurative languages in this poem.

\section{Spirit of the Dead}

This poem was 28 lines. There were 18 lines that used figurative language in the Spirits of the Death. From the table above the researchers found 14 kinds of figurative language in the poem.

\section{The Lake}

This poem first published in 1826 . There were 14 lines that used figurative language in The Lake. From the table above the researchers found 14 figurative languages in this poem.

\section{Evening Star}

This poem first published in 1845. The poem was 23 lines. There were 13 lines that used figurative language in Evening Star. From the table above the researchers found 10 figurative languages in the poem.

\section{Meanings of Figurative Language in Edgar Allan Poe's Poems}

Language is an instrument for conveying meaning as stated in previous chapter. According to Leech, there are 7 types of meaning, conceptual meaning, connotative meaning, social meaning, affective meaning, reflected meaning, collocative meaning, and thematic meaning. But in this research, the researchers 
just focused on 4 meanings, they are; connotative meaning, social meaning, reflected meaning and collocative meaning.

Figurative language belongs to non literal meaning. It has hidden or implicit meaning, meaning that what is said or written is not meant as what is said or written is. In this explanation below would describe the meanings of the Edgar Allan Poe's poems based on the using of figurative languages.

\section{Connotative Meaning}

The connotative meaning must be learned and mastered based on the language experience and the usage. Some of the connotative meaning had been written on the dictionary if these meaning become to general connotation. Based on the kinds of figurative language that had been found, the researchers found 42 connotative meanings of figurative language used in 8 Edgar Allan Poe's Poems.

\section{Social Meaning}

Social meaning is a piece of language conveys about the social circumstances of it use. It is connected with the situation in which an utterance is uttered. It was found 30 Social meanings of figurative language used in 8 Edgar Allan Poe's Poems.

\section{Reflected Meaning}

Reflected meaning is the meaning that arises in case of multiple conceptual meaning when one sense of a word forms part of our response to another sense. There were 16 reflected meanings of figurative language used in 8 Edgar Allan Poe's Poems.

\section{Collocative Meaning}

Collocative meaning consists of the association of a word acquires on account of the meanings of words which tend to occur in its environment. The researchers found 8 collocative meanings of figurative language used in 8 Edgar Allan Poe's Poems.

\section{DISCUSSION}

The researchers had analyzed the 8 poems by Edgar Allan Poe, entitled Annabel Lee, The Sleeper, A Dream Within A Dream, To One in Paradise, Alone, Spirit of the Death, The Lake and Evening Stars. The findings showed that Edgar Allan Poe used figurative language in his poems. Based on Abrams (1999:96), Figurative languages a conspicuous departure from what users of a language apprehend as the standard meaning of words, in order to achieve some special meaning or effect. According to Saputri (2014:22) "Figurative language is 
language that uses words or expressions with a meaning that is different from the literal interpretation." The used of figurative language had also made the poems sound more beautiful, and the used of such figures also made poems become more interesting to be read by the readers.

\section{Kinds of Figurative Language in Edgar Allan Poe's Poems}

Personification means giving human characteristics to an object. Based on the analyzing of the data, the researchers found 25 personifications used in 8 Edgar Allan Poe's poems. For example, In "Annabele Lee", For the moon never beams without bringing me dreams (Line 34). The poet uses figure of speech of personification in this line. The poet uses the word 'the moon' because he wants to give human sensibilities and human characteristics to the word 'moon', so this word as if acts like life-like being.

Simile is a kind of figurative meaning comparing two essentially unlike things. Based on the analyzing of the data, the researcher found 6 similes used in 3 Edgar Allan Poe's poems. The example of the sentences in the poems that used Simile in "The Sleeper" Looking like Lethe is see! the lake (line 13). This sentence includes figurative language of simile. The word 'like' as a figure of speech is the main feature. The sentence is to distinguish two unlike things: the 'Lethe' and 'the lake'.

Metaphor is a word expression that applied to a distinctly different kind of things, without asserting a comparison (Abrams, 1999:97). Based on the analyzing of the data, the researcher found 16 metaphors used in 8 Edgar Allan Poe's poems. The example of the sentences in the poems that used metaphor in "To One in Paradise" is And all my days are trances (line 19). That sentence above contains metaphor. The poet compares two unlike things as an indication sentence of metaphor 'all my days' with 'trances'.

Hyperbole is bold overstatement, or the extravagant exaggeration of fact or of possibility (Abrams 1999:120). Based on the analyzing of the data, the researchers found 12 hyperboles used in 6 Edgar Allan Poe's poems. The examples of the sentences in the poems that used hyperbole in "Alone" Of a most stormy life -- was drawn (line 10). This clause above is categorized as hyperbole. The poet uses the word 'stormy' in order to describe a childhood which shows the poet's life full of disasters.

Irony is a way of speaking or writing by saying something while the meaning is another (Abrams, 1999:135). Based on the analyzing of the data, the researchers found 2 Ironies used in 2 Edgar Allan Poe's poem. The examples of the sentences in the poems that used irony in "Alone" And all I lov'd -- I lov'd alone - (Line 8). The phrases are recognized as irony. It is because in fact, there is nobody wants to live alone. 
Paradox is a statement which seems on its face to be logically contradictory or absurd, yet turns out to be interpretable in a way that makes good sense (Abrams, 1999:201). Based on the analyzing of the data, the researcher found 9 paradoxes used in 7 Edgar Allan Poe's poems. The examples of the sentences in the poems that used paradox in "Spirit of The Dead" is The spirits of the dead who stood. The sentence above consist the figurative language of paradox. The poet uses the phrase 'the spirit of the dead' which has the contrast meaning with the traditional idea.

Metonymy is the literal term for one thing is applied to another with which it has become closely associated because of a recurrent relationship in common experience (Abrams, 1999: 98). Based on the analyzing of the data, the researcher found 6 metonymies used in 6 Edgar Allan Poe's poems. The examples of the sentences in the poems that used metonymy in "The Lake" An Eden of that dim lake. (line 23). The clause is recognized as metonymy. The word 'Eden' refers to 'paradise'. Meanwhile the words 'Dim lake' refers to death that was in the wave (the lake) and a grave for him which would bring him relief from his dark thoughts.

Symbolism is refers to person, situation, object or action which stands for something else more abstract. Based on the data analysis, the researchers found 21 symbolisms used in 8 Edgar Allan Poe's poems. The example of the sentences in the poems that used symbolism in "Annabele Lee" is So that her high-born kinsman came (Line 17). The phrase is considered as a symbolism. The words high-born kinsman refers of the angel of the death.

\section{The Meaning of Figurative Language in Edgar Allan Poe's Poems}

Figurative language belongs to non-literal meaning. The researchers concluded that Edgar Allan Poe used figurative language in his poems to convey meaning, beautify them, emphasize their meaning and enrich the meaning to the words. According to Leech, there are 7 types of meaning, conceptual meaning, connotative meaning, social meaning, affective meaning, reflected meaning, collocative meaning, and thematic meaning. The meanings of figurative language which are found by the researchers were connotative, social, reflected and collocative meanings.

\section{Connotative Meaning}

Connotation plays a major role in the language of literature, of politics, of advertising, and of song lyrics. Certain words or sentences convey a connotative meaning because of the figurative language usage or figure of speech. The researchers found 42 connotative meanings which was used in 8 Edgar Allan Poe's Poems. The poet uses some words which had unreal meaning or connotative 
meaning in order to make the poem become more beautiful and interesting to be read.

\section{Social Meaning}

Social meaning is based on the situation which an utterance is uttered and social circumstances of it use. The researchers found 30 social meanings which was used in 8 Edgar Allan Poe's Poems. The poet uses the social meanings in order to shows the readers about the social circumstances in this poem. For example the using of words 'thy, thou, thine' show the poetic sense in this poem. By this way, the poem can be flowery and interesting to be read.

\section{Reflected Meaning}

Reflected meaning is a language that has multiple conceptual meaning when one sense of our response means to another sense. In this research, the researchers found 16 reflected meanings which was used in 8 Edgar Allan Poe's Poems. The poet uses some reflected meanings in this poem to give the highten effects in the story of the poem. By using the words that have reflected meaning, the poet wants to make the readers use their imagination in understanding the poem.

\section{Collocative Meaning}

Collocative meaning consists of the association of a word acquires on account of the meanings of words which tend to occur in its environment. The researchers found only 8 collocative meanings which was used in 8 Edgar Allan Poe's Poems. Edgar Allan Poe's poem was written two centuries ago. Edgar Allan Poe used few collocative meanings in his poems. The most collocative meanings were found In "To One in Paradise". There are only 2 sentences which containts collocative meanings in this poem. But the researchers would give the example from "Spirit of the Dead' to represent the collocative meaning.

\section{CONCLUSION}

The research aimed to describe figurative language used in Edgar Allan Poe's poems. The objectives of the study are to explain the kinds of figurative language used in Edgar Allan Poe's poems and to describe the meanings of figurative language used in Edgar Allan Poe's poems. This research had analyzed and discussed about the kinds and meanings of figurative languages found in Edgar Allan Poe's poems such as Annabel Lee, The Sleeper, A Dream Within A Dream, Alone, To One in Paradise, Spirit of the Dead, The Lake and Evening Star. 
After analyzing the data, the researchers concluded some findings as follow: There were 96 figurative languages in 8 Edgar Allan Poe's poems, and the kinds of figurative language were 25 personifications, 6 similes, 16 metaphors, 11 hyperboles, 2 Ironies, 9 paradoxes, 6 metonymies, and 21 symbolisms. There were 42 connotative meanings, 30 social meanings, 16 reflected meanings and 8 collocative meaning found as figurative language meaning in the poems. The use of figurative language had also made the poems sound more beautiful, and the use of such figures also made poems attract the reader's attention. In the construction of this poem, the poet is aware of using figurative languages and it is used intentionally to strengthen the poem's meaning.

\section{REFERENCES}

Abrams, M. H. (1999). A Glossary of Literary Terms. (7th ed.). New York: Cornell University.

Agustini, E. (2016). Figurative Language in William Wordsworth's Poem "She Was a Phantom of Delight”. English Department, Faculty of Letters and Culture, Udayana University, Denpasar.

Bloomfield, L. (1933). Language. New York: Hold, Rinehart.

Childs, P., \& Fowlers, R. (2006). The routledge Dictionary of Literary terms. New York: Taylor \& Francis e-Library.

Crystal, D. (1999). A Dictionary of Linguistics and Phonetic. Cambridge: Basil Blackwell Ltd.

Fadaee, E. (2011). Symbolisms, metaphors and similes in literature: A casestudy of "Animal Farm". Journal of English and Literature, 2(2), 19-27.

Ingram, J. H. (Eds.). (1899). The works of Edgar Allan Poe. London: A. \& C. Black, Soho Square.

Iryanti, F. (2010). A Figurative Analysis on Sylvia Plath Poems. (Unpublished Undergraduated Thesis). Islamic University "Syarief Hidayatullah", Jakarta.

Knickerbocker, K. L., \& Williard R.H. (1963). Interpreting Literature. New York. Chicago. San Francisco. Toronto: Holt, Richard and Winston.

Leech, G. P. (1969). A Linguistic Guide to English Poetry. New York: Longman Inc.

(1981). Semantics: The Study of Meaning. (2nd ed.). London: Penguin Books.

Moleong, L. J. (2009). Metodology Penelitian Kualitatif. Bandung: Remaja Rosdakarya.

Padni, W. J. (2012). Imagery and Figurative Language In The Poem "A Dream Within A Dream" By Edgar Allan Poe. Jurusan Sastra Inggris, Universitas Udayana, Denpasar.

Peck, J., \& Coyle, M. (1984). Literary Terms and Criticsm. London: Macmillan Education LTD. 
Perrine, L. (1963). Sound and Sense: An Introduction to Poetry (2th ed.).New York: Southern Methodist Universitas

\& Thomas, R. (1983). Sound and Sense: An Introduction to Poetry. London: Southern Methodist University

Saputri, E. W. (2014). An Analysis of Figurative Languages Used In Rick Riordan's Novel. Faculty of Humanities, Dian Nuswantoro University, Semarang.

Suryani, A. T. (2013). An Analysis of Wole Soyinka's Poems: Figurative language cases. (Unpublished Undergraduate Thesis). English Department, STKIP-PGRI Jombang, Jombang 